University of Windsor

Scholarship at UWindsor

$11-17-2017$

\title{
Mercury exposure and short-term consequences on physiology and reproduction in Antarctic petrels
}

\author{
Alice Carravieri \\ Jérôme Fort \\ Arnaud Tarroux \\ Yves Cherel \\ Oliver P. Love \\ University of Windsor
}

See next page for additional authors

Follow this and additional works at: https://scholar.uwindsor.ca/biologypub

Part of the Biology Commons

\section{Recommended Citation}

Carravieri, Alice; Fort, Jérôme; Tarroux, Arnaud; Cherel, Yves; Love, Oliver P.; Prieur, Solène; Brault-Favrou, Maud; Bustamante, Paco; and Descamps, Sébastien, "Mercury exposure and short-term consequences on physiology and reproduction in Antarctic petrels" (2017). Environmental Pollution.

https://scholar.uwindsor.ca/biologypub/1196

This Article is brought to you for free and open access by the Department of Biological Sciences at Scholarship at UWindsor. It has been accepted for inclusion in Biological Sciences Publications by an authorized administrator of Scholarship at UWindsor. For more information, please contact scholarship@uwindsor.ca. 


\section{Authors}

Alice Carravieri, Jérôme Fort, Arnaud Tarroux, Yves Cherel, Oliver P. Love, Solène Prieur, Maud BraultFavrou, Paco Bustamante, and Sébastien Descamps 


\title{
Mercury exposure and short-term consequences on physiology and reproduction in Antarctic petrels ${ }^{\text {ir }}$
}

\author{
Alice Carravieri ${ }^{\mathrm{a},}{ }^{*}$, Jérôme Fort ${ }^{\mathrm{b}}$, Arnaud Tarroux ${ }^{\mathrm{c}}$, Yves Cherel ${ }^{\mathrm{a}}$, Oliver P. Love ${ }^{\mathrm{d}}$, \\ Solène Prieur ${ }^{\mathrm{b}}$, Maud Brault-Favrou ${ }^{\mathrm{b}}$, Paco Bustamante ${ }^{\mathrm{b}}$, Sébastien Descamps ${ }^{\mathrm{c}}$ \\ ${ }^{a}$ Centre d'Etudes Biologiques de Chizé (CEBC), UMR 7372 du CNRS-Université de La Rochelle, 79360 Villiers-en-Bois, France \\ ${ }^{\mathrm{b}}$ Littoral, Environnement et Sociétés (LIENSS), UMR 7266 du CNRS-Université de La Rochelle, 2 rue Olympe de Gouges, 17000 La Rochelle, France \\ ${ }^{\mathrm{c}}$ Norwegian Polar Institute, Fram Centre, 9296 Tromsø, Norway \\ d Department of Biological Sciences, University of Windsor, 401 Sunset Avenue, Windsor, Ontario, N9B 3P4, Canada
}

\section{A R T I C L E I N F O}

\section{Article history:}

Received 4 October 2017

Received in revised form

31 October 2017

Accepted 1 November 2017

Available online $\mathrm{xxx}$

\section{Keywords:}

Antarctica

Bioaccumulation

Body condition

Breeding success

Stable isotopes

Trophic position

\begin{abstract}
A B S T R A C T
Mercury ( $\mathrm{Hg}$ ) is a pervasive contaminant reaching Antarctic environments through atmospheric transport and deposition. Seabirds as meso to top predators can accumulate high quantities of $\mathrm{Hg}$ through diet. Reproduction is one of the most sensitive endpoints of $\mathrm{Hg}$ toxicity in marine birds. Yet, few studies have explored $\mathrm{Hg}$ exposure and effects in Antarctic seabirds, where increasing environmental perturbations challenge animal populations. This study focuses on the Antarctic petrel Thalassoica antarctica from Svarthamaren, Antarctica, where the world's largest breeding population is thought to be in decline. $\mathrm{Hg}$ and the stable isotopes of carbon $\left(\delta^{13} \mathrm{C}\right.$, proxy of feeding habitat) and nitrogen $\left(\delta^{15} \mathrm{~N}\right.$, trophic position/ diet) were measured in red blood cells from 266 individuals over two breeding years $(2012-13,2013$ -14 ). Our aims were to 1) quantify the influence of individual traits (size and sex) and feeding ecology (foraging location, $\delta^{13} \mathrm{C}$ and $\delta^{15} \mathrm{~N}$ values) on $\mathrm{Hg}$ exposure, and 2) test the relationship between $\mathrm{Hg}$ concentrations with body condition and breeding output (hatching success and chick survival). $\mathrm{Hg}$ concentrations in Antarctic petrels (mean $\pm \mathrm{SD}, 0.84 \pm 0.25$, min-max, $0.42-2.71 \mu \mathrm{g} \mathrm{g}^{-1} \mathrm{dw}$ ) were relatively low when compared to other Antarctic seabirds. Hg concentrations increased significantly with $\delta^{15} \mathrm{~N}$ values, indicating that individuals with a higher trophic level (i.e. feeding more on fish) had higher $\mathrm{Hg}$ exposure. By contrast, $\mathrm{Hg}$ exposure was not driven by feeding habitat (inferred from both foraging location and $\delta^{13} \mathrm{C}$ values), suggesting that $\mathrm{Hg}$ transfer to predators in Antarctic waters is relatively homogeneous over a large geographical scale. $\mathrm{Hg}$ concentrations were not related to body condition, hatching date and short-term breeding output. At present, $\mathrm{Hg}$ exposure is likely not of concern for this population. Nevertheless, further studies on other fitness parameters and long-term breeding output are warranted because $\mathrm{Hg}$ can have long-term population-level effects without consequences on current breeding success.
\end{abstract}

(c) 2017 Elsevier Ltd. All rights reserved.

\section{Introduction}

Increasing evidence shows that Antarctica is exposed to pervasive contaminants of natural and anthropogenic origins (Kallenborn et al., 2013; Mastromonaco et al., 2016). For instance, mercury (Hg), a non-essential metal, can travel long distances under its gaseous, elemental form (Fitzgerald et al., 2007) from its emission areas in industrialized countries through

\footnotetext{
* This paper has been recommended for acceptance by Maria Cristina Fossi.

* Corresponding author.

E-mail address: alice.carravieri@gmail.com (A. Carravieri).
}

atmospheric transport, and reach Antarctica (Mastromonaco et al., 2016). There, Hg enters marine and terrestrial environments through wet and dry deposition processes, especially, but not exclusively, during springtime atmospheric $\mathrm{Hg}$ depletion events (Ebinghaus et al., 2002; Mastromonaco et al., 2016). Although $\mathrm{Hg}$ is partly re-emitted into the air, a fraction of waterborne $\mathrm{Hg}$ is assimilated by phyto- and zooplankton, in particular when $\mathrm{Hg}$ is under its methylated form (Morel et al., 1998). Once assimilated, methyl-Hg biomagnifies up the food web, with increasing $\mathrm{Hg}$ concentrations in tissues of organisms at higher trophic levels (Atwell et al., 1998; Bargagli et al., 1998). Upper predators such as seabirds can thus be exposed to large 
quantities of $\mathrm{Hg}$ via food intake (Bargagli et al., 1998). Consequently, seabirds are increasingly used as bioindicators of $\mathrm{Hg}$ distribution in the marine environment, including the polar regions (Carravieri et al., 2016; Fort et al., 2014; Polito et al., 2016), and are susceptible to $\mathrm{Hg}$ toxicity both at the individual and population levels (Goutte et al., 2014a,b; Tartu et al., 2013, 2016). In contrast to the Arctic, where spatio-temporal trends and negative effects of seabird exposure to $\mathrm{Hg}$ are relatively wellknown (e.g., Bond et al., 2015; Braune et al., 2014a; Dietz et al., 2013; Fort et al., 2016, 2014; Goutte et al., 2015; Scheuhammer et al., 2015; Tartu et al., 2013), Hg occurrence and toxicity in Antarctic species are poorly studied. $\mathrm{Hg}$ exposure has mainly been assessed in penguins in a variety of tissues (Brasso et al., 2015; Carravieri et al., 2016) especially in West Antarctica (e.g., Ancora et al., 2002; Brasso et al., 2012; dos Santos et al., 2006; Jerez et al., 2011). By contrast, Antarctic flying seabirds have received much less attention (Tartu et al., 2014, 2015); most studies have reported $\mathrm{Hg}$ concentrations in eggs or tissues within a limited number of individuals, revealing similar levels to Arctic species, despite lower $\mathrm{Hg}$ concentrations in abiotic matrices (Bargagli et al., 1998; Calle et al., 2015; Cipro et al., 2017a; Nygård et al., 2001). Flying seabirds usually have larger foraging ranges than penguins during the breeding and/or wintering periods (BirdLife International, 2004), and thus visit a larger range of sites with potentially contrasting $\mathrm{Hg}$ bioavailability. As such, flying seabirds may be more at risk of exposure to high quantities of $\mathrm{Hg}$.

$\mathrm{Hg}$ is a potent neurotoxin and an endocrine disruptor (Tan et al., 2009; Wolfe et al., 1998), and it has also been associated with decreased body condition and immune responses (Scheuhammer et al., 2007; Wayland et al., 2002). In aquatic and marine birds, reproduction is one of the most sensitive endpoints of toxicity (Evers et al., 2008; Wolfe et al., 1998). Specifically, Hg can reduce egg hatchability and embryo survival (Scheuhammer et al., 2007), but it can also impact parents' breeding decisions, behaviour and investment (Evers et al., 2008; Goutte et al., 2015; Tartu et al., 2013, 2015), with negative fitness consequences such as decreased breeding success over the short- and long-term (Evers et al., 2008; Goutte et al., 2014a,b). Antarctic species may be particularly sensitive to the toxic effects of contaminants as they have to cope with multiple additional environmental stressors in this rapidly changing, extreme environment (Barbraud and Weimerskirch, 2001; Descamps et al., 2015; Goutte et al., 2014a). Therefore, more studies are required to determine $\mathrm{Hg}$ concentrations and effects in Antarctic flying bird species and thereby fully grasp exposure, toxic effects and ultimately population-level consequences of $\mathrm{Hg}$ in this region.

In this context, the present study focuses on the Antarctic petrel Thalassoica antarctica, from Svarthamaren, Dronning Maud Land, Antarctica. The Antarctic petrel is a long-lived, middle-sized seabird and one of the least-studied Antarctic species. Svarthamaren hosts the largest known colony of this seabird, totalling 200000 breeding pairs historically (Mehlum et al., 1988; van Franeker et al., 1999). However, lower numbers have been reported recently $(<100000$ breeding pairs, Descamps et al., 2016a and unpublished data), and the population is thought to be in overall decline. Evaluating exposure and potential negative effects of $\mathrm{Hg}$ in this population is thus a pressing priority. The present study has two main aims: first, to quantify $\mathrm{Hg}$ exposure and disentangle the influence of individual traits (body size and sex) and feeding ecology on $\mathrm{Hg}$ concentrations, and second, to relate individual $\mathrm{Hg}$ exposure to fitness components. To this end, $\mathrm{Hg}$ burdens were quantified in blood in a large number of individuals across two consecutive breeding years. Blood is considered to be an excellent tool to evaluate $\mathrm{Hg}$ exposure in seabirds: circulating quantities are representative of recent dietary intake and are in equilibrium with internal tissue burdens (Bearhop et al., 2000; Fort et al., 2015; Fromant et al., 2016). Feeding ecology was evaluated by measuring blood values of the stables isotopes of carbon $\left(\delta^{13} \mathrm{C}\right)$ and nitrogen $\left(\delta^{15} \mathrm{~N}\right)$, which are chemical proxies of feeding habitat and trophic position, respectively (Newsome et al., 2007), and by equipping birds with Global Positioning System (GPS) loggers. During the breeding period, Antarctic petrels forage in high Antarctic waters over a large spatial scale, travelling up to $2000 \mathrm{~km}$ from the colony (Descamps et al., 2016b). Latitudedependent $\mathrm{Hg}$ exposure has been previously shown in subantarctic (Carravieri et al., 2014a) and Antarctic (Tartu et al., 2014) seabirds. We thus predicted a geographical variation in exposure in individuals feeding at distant oceanic sites. Antarctic petrels are mainly krill-eaters, but their diet at Svarthamaren also includes a variable proportion of fish and squid (Descamps et al., 2016b). Given the biomagnifying properties of $\mathrm{Hg}$, we predicted individuals with higher $\delta^{15} \mathrm{~N}$ values (i.e. feeding at higher trophic positions) to bear higher $\mathrm{Hg}$ concentrations. Considering previous evidence of $\mathrm{Hg}$ effects on polar seabirds, we predicted individuals with high $\mathrm{Hg}$ concentrations to have a low body condition index and decreased breeding output (later hatching date, lower hatching success and chick survival) (Tartu et al., 2014, 2015).

\section{Material and methods}

\subsection{Study site and sampling procedure}

Fieldwork was carried out at the Svarthamaren Antarctic petrel colony $\left(71^{\circ} 53^{\prime} \mathrm{S}, 5^{\circ} 10^{\prime} \mathrm{E}\right)$ where Antarctic petrels lay a single egg at the end of November/early December. Chicks hatch around midJanuary and fledge early March. Both parents contribute to incubation and chick rearing, with the chick being continuously guarded for the first 7-15 days following hatching (Lorentsen and Røv, 1995). A total of 266 breeding individuals were captured during incubation or chick brooding over two breeding years (2012-13 and 2013-14). After taking morphometric measures (see section 2.2.), a small amount of blood $(<2 \mathrm{ml})$ was sampled from the brachial vein, and temporarily preserved unfrozen in heparinized microtubes until being centrifuged. Red blood cells and plasma were then kept frozen in separate microtubes until subsequent analyses (see section 2.3). Some individuals $(\mathrm{N}=91)$ were equipped with GPS loggers, which were attached to tail feathers using Tesa $^{\circledR}$ tape (Descamps et al., 2016b; Tarroux et al., 2016; see also section 2.4.). Birds were immediately released onto their nests after handling, which typically lasted $10-20 \mathrm{~min}$. Upon retrieval, GPS birds were sampled for blood again and weighed following the same procedures. In addition, all nests were monitored every other day on average from incubation to chick-rearing as presented in Descamps et al. (2015), to estimate hatching date, hatching success and chick survival. For logistical reasons, nests could not be monitored until fledging and chick survival was therefore estimated 15 days after hatching.

\subsection{Morphological measurements and body condition index}

Birds were weighed with a 1000-g Pesola balance (precision $\pm 5 \mathrm{~g}$ ), their bill height and culmen measured with a calliper $( \pm 0.1 \mathrm{~mm})$, and their wing length measured with a ruler $( \pm 1.0 \mathrm{~mm})$. In order to define body condition, the "scaled mass index" (Peig and Green, 2010, 2009), hereafter SMI, was calculated following Meillère et al. (2015). This body condition index adjusts the mass of all individuals to that expected if they had the same body size (Peig and Green, 2009). 


\subsection{Hg, stable isotope analyses and molecular sexing}

Total $\mathrm{Hg}$ (hereafter "Hg") was quantified at the laboratory Littoral, Environment and Societies (LIENSs) from lyophilized and homogenised red blood cells with an Altec AMA 254 spectrophotometer (aliquots mass: $\sim 5 \mathrm{mg}$ dry weight, $\mathrm{dw}$ ) as described in Bustamante et al. (2006). All analyses were carried out in duplicate, and the relative standard deviation (SD) for each individual was $<10 \%$. Accuracy was checked using a certified reference material (CRM, TORT-2 Lobster Hepatopancreas, NRC, Canada; certified Hg concentration: $0.27 \pm 0.06 \mu \mathrm{g} \mathrm{g}^{-1} \mathrm{dw}$ ) every five samples. Measured values were $0.26 \pm 0.01 \mu \mathrm{g} \mathrm{g}^{-1} \mathrm{dw}, \mathrm{N}=103$. Mass of the CRM was adjusted to represent an amount of $\mathrm{Hg}$ similar to that in red blood cell samples. Blanks were analysed at the beginning of each set of samples and the limit of detection was $0.005 \mu \mathrm{g} \mathrm{g}^{-1} \mathrm{dw}$.

Carbon $\left(\delta^{13} \mathrm{C}\right)$ and nitrogen $\left(\delta^{15} \mathrm{~N}\right)$ stable isotope ratios were determined in red blood cells and delipidated plasma at the laboratory LIENSs with a continuous flow mass spectrometer (Thermo Scientific Delta V Advantage) coupled to an elemental analyser (Thermo Scientific Flash EA 1112) (aliquots mass: $\sim 0.3 \mathrm{mg} \mathrm{dw}$ ). Results are in $\delta$ notation relative to Vienna PeeDee Belemnite and atmospheric $\mathrm{N}_{2}$ for $\delta^{13} \mathrm{C}$ and $\delta^{15} \mathrm{~N}$, respectively. Accuracy of the mass spectrometer was checked using internal laboratory standards (acetanilide) which showed measurement errors $<0.15 \%$ for both $\delta^{13} \mathrm{C}$ and $\delta^{15} \mathrm{~N}$. We evaluated the overall precision of measurement by duplicating a random subset of 22 samples (Jardine and Cunjak, 2005). The mean absolute difference between duplicates was $0.05 \%$ o (range $=[0 ; 0.14]$ ), and $0.05 \%$ o (range $=[0.02$; $0.10])$, respectively for $\delta^{13} \mathrm{C}$ and $\delta^{15} \mathrm{~N}$.

Gender was determined in a subsample of individuals $(\mathrm{N}=139)$ after DNA extraction and polymerase chain reaction (PCR) amplification of CHD genes using primers from Fridolfsson and Griffiths. Genes were separated in $2 \%$ agarose gel by electrophoresis. Briefly, copies of CHD genes are present in both $\mathrm{Z}$ and $\mathrm{W}$ bird sexual chromosomes. CHD-Z and CHD-W genes differ in the base pair length of their non-coding regions. Because females are heterogametic (ZW) and males homogametic (ZZ), separation of gene amplification products by size results in a single band for males and two bands for females. DNA extraction negative controls were included for every runs.

\subsection{GPS tracking}

GPS (CatTrack 1, Catnip Technologies Ltd., Anderson, USA; $25 \times 45 \times 9 \mathrm{~mm}$, ca. $20 \mathrm{~g}$ with a shrink tube used for waterproofing) were used to estimate the location of birds' foraging grounds during one or two consecutive trips (Descamps et al., 2016b; Tarroux et al., 2016). GPS units were programmed to record bird position every 5-90 $\mathrm{min}$ (median $=10 \mathrm{~min}$ ) and were deployed for an average of 11 days $(\min =2 \mathrm{~d}$, $\max =28 \mathrm{~d}$ ). From GPS recordings, latitude and longitude of the furthest location from the breeding colony were extracted and used as a proxy for an individual's foraging ground. Only complete foraging trips (i.e. trips with data recorded until birds returned to the colony) were considered. To validate the consistency of foraging grounds used over time by individual birds, we investigated the relationship between $\delta^{13} \mathrm{C}$ values in plasma and red blood cells. $\delta^{13} \mathrm{C}$ values indeed have contrasted turn-over rates in plasma (a few days, thus corresponding well to the period of GPS tracking) and in red blood cells (several weeks) (Hobson and Clark, 1993) meaning that $\delta^{13} \mathrm{C}$ values measured in both plasma and red blood cells are indicators of the short- and medium-term feeding habitats, respectively. We found a strong positive relationship between $\delta^{13} \mathrm{C}$ values measured in these two tissues $\left(\mathrm{R}^{2}=0.59, \mathrm{~F}_{1,20}=30.79, \mathrm{p}<0.001\right)$, indicating that birds show consistent feeding habitats over the medium term (Xavier et al., 2017). All analyses were thus carried out on red blood cell sample data (hereafter "blood").

\subsection{Statistical analyses}

Statistical analyses were carried out using R 3.3.2 (R Core Team, 2016). Sample sizes varied depending on the dependent variable studied, as summarised in Table S1. In a first step, the relationship between feeding ecology (inferred from blood $\delta^{13} \mathrm{C}$ and $\delta^{15} \mathrm{~N}$ values), foraging ground (inferred from the latitude and longitude of the furthest location from the breeding colony), sampling date and breeding years and blood $\mathrm{Hg}$ concentrations was assessed through a generalized linear model (GLM) with a gamma distribution and a log link function. This model specification is appropriate for continuous, positive dependent variables with a positive skew (i.e. non-normal, with a long tail on the right, Crawley, 2007), a pattern that was present here and that is overall common in the distribution of contaminant concentrations. Only $\mathrm{Hg}$ and stable isotope data at GPS retrieval were considered, so that GPS tracking, blood $\mathrm{Hg}$ and stable isotope values were representative of a similar time window. The variable "sampling date" was included in models as the number of days from the 1 st of December of the respective breeding year. The maximal model was set as $\mathrm{Hg} \sim \delta^{13} \mathrm{C}+\delta^{15} \mathrm{~N}+$ date + latitude + longitude + sex + year. All potential biological models without interactions were compared using the Bayesian Information Criterion (BIC), and a relative weight of evidence ( $w_{i}$ normalized model likelihood given the set of models) was calculated for each model (Burnham and Anderson, 2002). The explanatory power of a given model was judged by the explained deviance adjusted for sample size and number of parameters. The effect of explanatory variables was interpreted by their parameter estimates (slope \pm standard error, SE) in the selected model.

In a second step, relationships between blood $\mathrm{Hg}$ concentrations and physiological (SMI) and fitness parameters (hatching date and success, chick survival) were examined on a larger sample size including also birds that were not equipped with GPS loggers (Table S1). Mixed-effect models (function lme from the nlme package, Pinheiro et al., 2017) were fitted using maximum likelihood (ML) as follows: physiological/fitness parameter $\sim \mathrm{Hg}+\delta^{15} \mathrm{~N}+$ sampling date + year $(+$ breeding status for SMI and chick survival data). These covariates were included in order to adjust for potential confounding effects. In particular, $\delta^{15} \mathrm{~N}$ was included as results from the first step indicated a significant association between $\delta^{15} \mathrm{~N}$ and $\mathrm{Hg}$ (see Results). The significance of the relationship between $\mathrm{Hg}$ and the physiological/fitness parameters was examined using log-likelihood ratio tests (LRT) between models including or removing the term "Hg". Hatching date was analysed as the number of days from the 1st of December of the respective breeding year. Model assumptions were checked through visual inspection of the residuals. For binomial models, model fit was checked through the overdispersion term value. All results are mean $\pm \mathrm{SD}$.

\section{Results}

\subsection{Explanatory factors of $\mathrm{Hg}$ concentrations}

We detected quantifiable concentrations of $\mathrm{Hg}$ in all individuals: $0.84 \pm 0.25$ (range $0.42-2.71$ ) $\mu \mathrm{g} \mathrm{g}^{-1} \mathrm{dw}$ (Table 1 ). Blood $\mathrm{Hg}$ concentrations in males and females, as well as during the 2012-13 and 2013-14 breeding years are presented in Table 1 and Table S2. Blood $\delta{ }^{13} \mathrm{C}$ values in individuals equipped with GPS units ranged from -26.4 to $-25.0 \%$ (Table 1 ), while blood $\delta^{15} \mathrm{~N}$ values ranged from 8.3 to $10.2 \%$ (Table 1 ). The most parsimonious model for 
Table 1

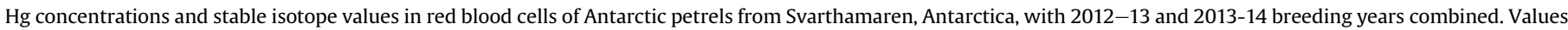
are mean \pm SD with range in parenthesis.

\begin{tabular}{|c|c|c|c|c|c|}
\hline & & $\mathrm{N}$ & $\mathrm{Hg}\left(\mu \mathrm{g} \mathrm{g}^{-1} \mathrm{dw}\right)$ & $\delta^{13} \mathrm{C}(\% 0)$ & $\delta^{15} \mathrm{~N}(\% 0)$ \\
\hline $\begin{array}{l}\text { All sampled } \\
\text { individuals }\end{array}$ & $\begin{array}{l}\text { All } \\
\text { F } \\
\text { M }\end{array}$ & $\begin{array}{l}266 \\
88 \\
79\end{array}$ & $\begin{array}{l}0.84 \pm 0.25(0.42-2.71) \\
0.83 \pm 0.24(0.44-2.04) \\
0.83 \pm 0.23(0.48-1.81)\end{array}$ & $\begin{array}{l}-25.2 \pm 0.5(-26.4-24.1) \\
-25.2 \pm 0.4(-26.3-24.4) \\
-25.3 \pm 0.6(-26.3-24.1)\end{array}$ & $\begin{array}{l}9.7 \pm 0.5(8.2-10.9) \\
9.6 \pm 0.5(8.2-10.6) \\
9.7 \pm 0.4(8.8-10.7)\end{array}$ \\
\hline $\begin{array}{l}\text { GPS } \\
\text { individuals }\end{array}$ & $\begin{array}{l}\text { All } \\
\text { F } \\
\text { M }\end{array}$ & $\begin{array}{l}91 \\
48 \\
43\end{array}$ & $\begin{array}{l}0.80 \pm 0.20(0.45-1.62) \\
0.83 \pm 0.22(0.56-1.62) \\
0.75 \pm 0.18(0.45-1.17)\end{array}$ & $\begin{array}{l}-25.7 \pm 0.3(-26.4-25.0) \\
-25.6 \pm 0.3(-26.4-25.1) \\
-25.7 \pm 0.4(-26.4-25.0)\end{array}$ & $\begin{array}{l}9.2 \pm 0.4(8.3-10.2) \\
9.2 \pm 0.4(8.3-10.2) \\
9.2 \pm 0.3(8.5-10.1)\end{array}$ \\
\hline
\end{tabular}

Table 2

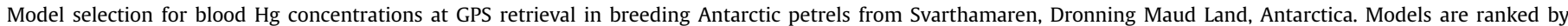

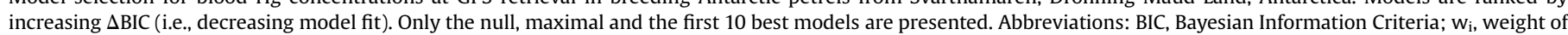

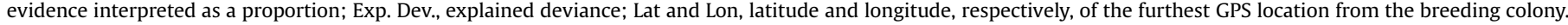

\begin{tabular}{|c|c|c|c|c|c|}
\hline Models & $k^{\mathrm{a}}$ & BIC & $\Delta \mathrm{BIC}$ & $w_{\mathrm{i}}^{\mathrm{b}}$ & Exp. Dev. $(\%)^{c}$ \\
\hline \multicolumn{6}{|c|}{ Maximal model: $\mathrm{Hg} \sim \delta^{13} \mathrm{C}+\delta^{15} \mathrm{~N}+$ Lat + Lon + Year + Sex + Date } \\
\hline $\mathrm{Hg} \sim \delta^{15} \mathrm{~N}+$ Date + Sex & 4 & -52.97 & 0 & 0.62 & 27.5 \\
\hline $\mathrm{Hg} \sim \delta^{15} \mathrm{~N}+$ Date + Year + Sex & 5 & -48.88 & 4.10 & 0.08 & 27.8 \\
\hline $\mathrm{Hg} \sim \delta^{15} \mathrm{~N}+$ Date + Lat + Sex & 5 & -48.80 & 4.17 & 0.08 & 27.8 \\
\hline $\mathrm{Hg} \sim \delta^{13} \mathrm{C}+\delta^{15} \mathrm{~N}+$ Date + Sex & 5 & -48.48 & 4.50 & 0.07 & 27.5 \\
\hline $\mathrm{Hg} \sim \delta^{15} \mathrm{~N}+$ Date + Lon + Sex & 5 & -48.47 & 4.50 & 0.07 & 27.5 \\
\hline $\mathrm{Hg} \sim \delta^{15} \mathrm{~N}+$ Date & 3 & -47.69 & 5.28 & 0.04 & 19.3 \\
\hline $\mathrm{Hg} \sim \delta^{15} \mathrm{~N}+$ Date + Lat & 4 & -45.31 & 7.66 & 0.01 & 21.2 \\
\hline $\mathrm{Hg} \sim \delta^{15} \mathrm{~N}+$ Date + Lat + Year + Sex & 6 & -44.89 & 8.09 & 0.01 & 28.2 \\
\hline $\mathrm{Hg} \sim \delta^{13} \mathrm{C}+\delta^{15} \mathrm{~N}+$ Date + Year + Sex & 6 & -44.51 & 8.47 & 0.01 & 28.0 \\
\hline $\mathrm{Hg} \sim \delta^{15} \mathrm{~N}+$ Date + Lon + Year + Sex & 6 & -44.39 & 8.58 & 0.01 & 27.9 \\
\hline Null model & 1 & -36.98 & 15.99 & 0.00 & 0.00 \\
\hline Maximal model & 8 & -36.31 & 16.66 & 0.00 & 0.29 \\
\hline
\end{tabular}

a Number of parameters.

b Weights across all models (not all shown) sum to 1.00

c Explained deviance adjusted by $k$ and $\mathrm{N}$.

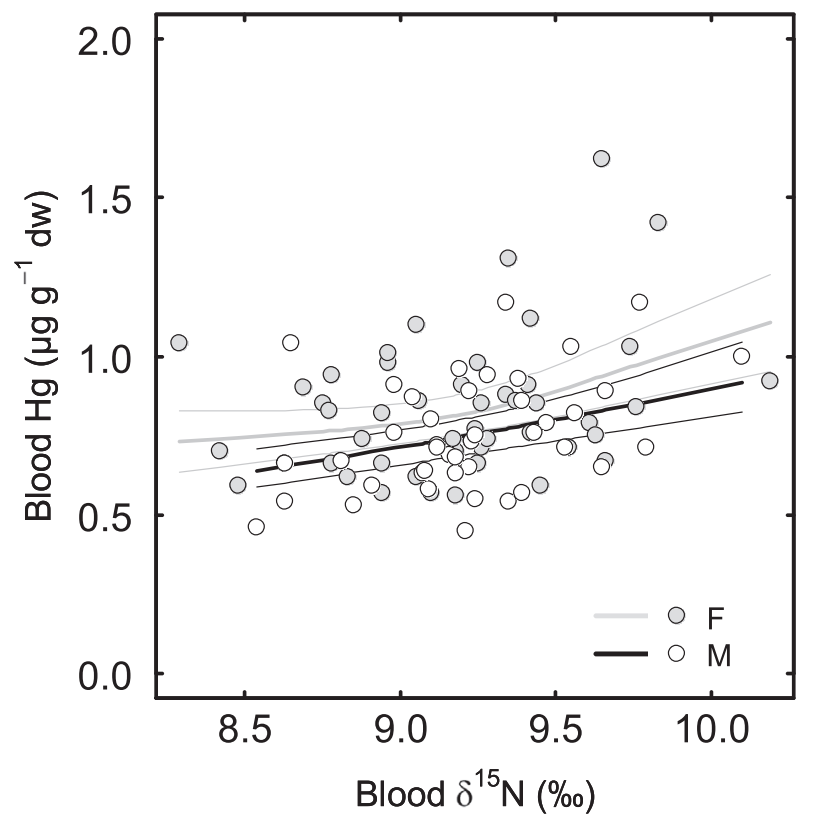

Fig. 1. Blood $\mathrm{Hg}$ concentrations increase with increasing $\delta^{15} \mathrm{~N}$ values in breeding Antarctic petrels from Svarthamaren, Dronning Maud Land, Antarctica. The represented model corresponds to the most parsimonious model from Table 1.

explaining blood $\mathrm{Hg}$ concentrations (Table 2) included the effect of $\delta^{15} \mathrm{~N}$ values (estimate $\pm \mathrm{SE}, 0.228 \pm 0.065, p<0.001$, Fig. 1 ), sex (males: $-0.141 \pm 0.046, p=0.003$ ) and sampling date, although the effect size was very small $(0.004 \pm 0.001, p=0.008$, Table 2$)$.
Models including maximum latitude or longitude of foraging trips, or $\delta^{13} \mathrm{C}$ values, had less support $(\Delta \mathrm{BIC}>2$, Table 2$)$.

\subsection{Hg relationships with SMI and reproductive parameters}

SMI values were not significantly related to blood $\mathrm{Hg}$, when taking into account $\delta^{15} \mathrm{~N}$, sampling date, year, status $(-17.12 \pm 18.01$, LRT: $\mathrm{LR}=0.92, p=0.338, \mathrm{~N}=258$, Table S1 $)$, and $\operatorname{sex}(18.01 \pm 22.49, \mathrm{LR}=0.66, p=0.418, \mathrm{~N}=163$, Table S1). The relationship between blood $\mathrm{Hg}$ concentrations and hatching date and success was tested in incubating individuals. The mean hatching date was January 15 th ( \pm 2 days) in $2012-13$ and January 16th ( \pm 3 days) in 2013-14, and was not related to blood $\mathrm{Hg}$ concentrations in incubating individuals $(2.38 \pm 1.66, \mathrm{LR}=2.23$, $p=0.136, \mathrm{~N}=52$, Table $\mathrm{S} 1$ ), even when an individual's sex was accounted for $(2.68 \pm 1.98, \mathrm{LR}=2.14, p=0.144, \mathrm{~N}=36$, Table S1 $)$. Hatching success in the sampled population was higher in 2012-13 than in 2013-14 (54\% and 33\%, respectively), but it was not related to blood $\mathrm{Hg}$ concentrations in incubating individuals $(0.01 \pm 0.75$, LR $<0.001, p=0.980, \mathrm{~N}=175$, Table S1) also when taking sex into account $(0.40 \pm 0.82, \mathrm{LR}=0.22, p=0.639, \mathrm{~N}=115$, Table $\mathrm{S} 1)$. Survival of chicks 15 days after hatching was higher in 2012-13 than in 2013-14 (58\% and 36\%, respectively), but again it was not related to their parent blood $\mathrm{Hg}$ concentrations $(0.47 \pm 0.56$, $\mathrm{LR}=0.635, p=0.426, \mathrm{~N}=106$, Table S1), even when an individual's sex was accounted for $(0.28 \pm 0.78, \mathrm{LR}=0.14, p=0.713, \mathrm{~N}=70$, Table S1).

\section{Discussion}

This study is a comprehensive evaluation of the causes and consequences of $\mathrm{Hg}$ exposure in an Antarctic flying seabird, 
focusing on one of the least known seabird species in this region, the Antarctic petrel. Overall, our results demonstrate low blood $\mathrm{Hg}$ concentrations in breeding birds with no apparent link to reproductive output. Results also provide new important information regarding the role played by avian trophic ecology on exposure to $\mathrm{Hg}$ at a time when rapidly-changing environmental conditions in polar regions (and in Antarctica in particular) might modify ecosystem functioning, food web structure, and $\mathrm{Hg}$ bioavailability to top predators.

\subsection{Hg exposure: trophic ecology and other explanatory factors}

When compared to other flying seabirds from Antarctica, Antarctic petrels generally had low $\mathrm{Hg}$ concentrations. Specifically, the fish-eating snow petrel Pagodroma nivea and the penguin-eating Antarctic skua Catharacta maccormicki from Adélie Land had approximately two-three times higher blood (Goutte et al., 2014a,b; Tartu et al., 2014, 2015) and tissue burdens (Nygård et al., 2001). By contrast, Antarctic petrels had higher blood $\mathrm{Hg}$ concentrations than krill-eating Antarctic penguins (Polito et al., 2016; authors' unpublished data). Interestingly, $\mathrm{Hg}$ blood burdens in Antarctic petrels were very similar to those of chinstrap penguins Pygoscelis antarctica, which feed mainly on Antarctic krill Euphasia superba and to a lesser extent on mesopelagic fish (Polito et al., 2016). Antarctic petrels also feed mainly on krill, although they feed on fish and squid as well (Descamps et al., 2016b; Lorentsen et al., 1998). The similar burdens between chinstrap penguins and Antarctic petrels are therefore not surprising. Feeding ecology is indeed considered to be the main driver of $\mathrm{Hg}$ exposure in seabirds, in contrast to intrinsic factors such as phylogeny (Carravieri et al., 2014b). In particular, trophic position plays a pivotal role, because of $\mathrm{Hg}$ biomagnifying properties (Atwell et al., 1998; Bargagli et al., 1998). Accordingly, blood $\delta^{15} \mathrm{~N}$ values were the main driver of blood $\mathrm{Hg}$ concentrations in Antarctic petrels: individuals with higher blood $\delta^{15} \mathrm{~N}$ values (i.e. with likely higher proportions of fish in their diet (Cherel et al., 2014) had significantly higher blood Hg concentrations than those with lower $\delta^{15} \mathrm{~N}$ values (i.e. feeding more largely on krill (Fig. 1). Inter-specific differences in seabird $\mathrm{Hg}$ concentrations are usually explained by $\delta^{15} \mathrm{~N}$ values, especially in blood, where the time integrations of $\mathrm{Hg}$ and $\delta^{15} \mathrm{~N}$ match (Anderson et al., 2009; Bearhop et al., 2000; Bond and Diamond, 2009). However, such a clear effect within one single seabird population is rarely observed (Tartu et al., 2014), specifically when variation in $\delta^{15} \mathrm{~N}$ values is relatively small ( $2 \%$, i.e. less than one trophic level, Newsome et al., 2007). This result thus suggests that the mesopelagic fish prey of Antarctic petrels has disproportionately higher $\mathrm{Hg}$ content than krill, as has been reported from other sites in the Southern Ocean (Anderson et al., 2009; Cipro et al., 2017b; Polito et al., 2016). Consequently, even a small proportion of fish in the diet of some individuals likely critically increased their $\mathrm{Hg}$ exposure. This also highlights that $\mathrm{Hg}$ measurements in the prey of Antarctic petrels prey are urgently needed to validate our results and further help determining potential risks of $\mathrm{Hg}$ exposure for Antarctic seabirds and other marine top predators.

Very negative blood $\delta^{13} \mathrm{C}$ values indicate that Antarctic petrels fed strictly in high Antarctic waters (Cherel, 2008, Cherel et al., 2011) across a very wide longitudinal range, as shown by GPS tracking (Descamps et al., 2016b). Contrary to our prediction though, feeding habitat showed no significant relationship with $\mathrm{Hg}$ exposure, as shown by the poor support of models including $\delta^{13} \mathrm{C}$ values and the location of the most distant foraging grounds (Table 2). Hg exposure thus appeared to be homogeneous over the vast oceanic region exploited by Antarctic petrels. This is consistent with previous results in Antarctic penguins; different populations from all around the Antarctic Peninsula had very similar $\mathrm{Hg}$ concentrations, thus suggesting homogeneity of $\mathrm{Hg}$ bioavailability in high Antarctic waters over large geographical scales (Brasso et al., 2012). This assertion is also supported by results in Antarctic prions Pachyptila desolata at South Georgia, which also feed primarily on Antarctic krill and secondarily on mesopelagic fish (Reid et al., 1997), and which have a similar blood $\mathrm{Hg}$ concentration to Antarctic petrels (Anderson et al., 2009). The homogeneity of $\mathrm{Hg}$ transfer to predators in high Antarctic waters contrasts with results in subantarctic and subtropical waters of the Southern Ocean, where $\mathrm{Hg}$ transfer to predators shows a latitudinal gradient increasing northward (Carravieri et al., 2014a, 2017). The sharp differences in physico-chemical properties between the water masses of the Southern Ocean could drive different rates of $\mathrm{Hg}$ deposition, re-emission to the air, and methylation in the water column (Fitzgerald et al., 2007), ultimately explaining the contrasting $\mathrm{Hg}$ transfer to predators at different latitudes. Hg exposure has been shown to differ depending on latitude also in Arctic seabirds (higher concentrations in the high Arctic, Braune et al., 2014b), likely as a consequence of dietary differences or of atmospheric $\mathrm{Hg}$ sources at low and high latitudes. The homogeneity of $\mathrm{Hg}$ exposure highlighted here thus appears to be specific to Antarctica.

Male and female Antarctic petrels had similar blood Hg concentrations (Table 1). Yet, when considering individuals equipped with GPS loggers, sex significantly predicted $\mathrm{Hg}$ exposure while accounting for feeding strategies (Table 2), with females having slightly higher $\mathrm{Hg}$ concentrations than males (Fig. 1). This result was unexpected, first because females partly excrete accumulated $\mathrm{Hg}$ to their eggs (Agusa et al., 2005), and second because sexrelated differences in $\mathrm{Hg}$ burdens in seabirds are often the result of sexual segregation in feeding ecology (Carravieri et al., 2014a; Robinson et al., 2012). In Antarctic petrels though blood $\delta^{13} \mathrm{C}$ and $\delta^{15} \mathrm{~N}$ values, and feeding tactics (Descamps, unpublished data) were similar between sexes. Hence, despite statistical significance, this result does not seem biologically meaningful. Alternatively, the higher concentrations in females could stem from: i) sex-related physiological differences in $\mathrm{Hg}$ kinetics in the organism (absorption, internal organ storage, and excretion), ii) sex-related differences in diet, during the breeding or wintering periods, that are not mirrored in blood $\delta^{13} \mathrm{C}$ and $\delta^{15} \mathrm{~N}$ values, or iii) other direct or indirect unknown factors (Provencher et al., 2016). Further studies, and in particular a detailed description of sex-specific prey choice, could help to verify the sex-related difference in $\mathrm{Hg}$ accumulation depicted here.

Antarctic petrels blood $\mathrm{Hg}$ concentrations increased slightly during the breeding season (i.e. effect of the date of capture), although the effect was very weak. Temporal variation in blood $\mathrm{Hg}$ concentrations could be the result of intrinsic factors, such as $\mathrm{Hg}$ accumulation in internal tissues before moult, when a large proportion of $\mathrm{Hg}$ can be excreted into feathers (Monteiro and Furness, 2001), or due to physiological changes related to breeding status. Nonetheless, extrinsic factors could also be involved, such as a diet change over time, for example as a result of an increase of food intake to counterbalance higher energy expenditure along with the increasing nutritional needs of growing chicks. In addition, there could be a temporal variability in $\mathrm{Hg}$ bioavailability in food webs (Braune et al., 2014a). Nevertheless, disentangling the influence of such complex intrinsic and extrinsic factors is beyond the scope of the present study. In addition, longitudinal investigations on temporal changes in $\mathrm{Hg}$ concentrations in wild seabirds' tissues are still dramatically lacking. On the other hand, blood $\mathrm{Hg}$ concentrations were not significantly related to the year of sampling, highlighting low inter-annual variability in exposure over the short-term, as usually observed at oceanic sites far from $\mathrm{Hg}$ point sources (Brasso et al., 2014; Carravieri et al., 2016). 
In conclusion, even though feeding ecology, sex, and capture date were significant predictors of $\mathrm{Hg}$ exposure in breeding Antarctic petrels, a large component of individual variation in blood $\mathrm{Hg}$ concentrations $(\sim 70 \%)$ remained unexplained. In the current study the age of the birds was unknown, and even though age-related changes in blood $\mathrm{Hg}$ concentrations in adult seabirds are usually not significant or weak (Carravieri et al., 2014a; Tartu et al., 2014; Tavares et al., 2013), taking age into account may have explained some of the remaining variation in $\mathrm{Hg}$ burdens. Other factors, such as individual-specific excretion capacities in the feathers (Bearhop et al., 2000), demethylation capacity in the liver, or rate of absorption in the gut, in addition to extrinsic factors such as individual-specialisation on particular prey species (Anderson et al., 2009; Polito et al., 2016), could all have played a role and merit further investigation.

\subsection{Effects of $\mathrm{Hg}$ on physiology and fitness components}

Very few studies have established threshold levels of $\mathrm{Hg}$ deleterious effects in wild bird populations, because of the need to quantify several endpoints of toxicity (physiological, behavioural, and reproductive), to follow populations over the long-term, and because of the difficulty, for ethical reasons, of experimentally manipulating exposure in protected species (Evers et al., 2008; Goutte et al., 2015). However, studies on the common loon Gavia immer, an obligate piscivorous bird, showed that blood concentrations $>3.0 \mu \mathrm{g} \mathrm{g}^{-1}$ ww $\left(\sim 12.0 \mu \mathrm{g} \mathrm{g}^{-1} \mathrm{dw}\right)$ were associated with reproductive impairment (Evers et al., 2008). Similarly, the most contaminated male snow petrels $\left(\sim 2 \mu \mathrm{g} \mathrm{g}^{-1} \mathrm{dw}\right)$ were more prone to neglect their egg during incubation, likely as a result of hormonal disruption (Tartu et al., 2015). Blood Hg concentrations in snow petrels were lower than the common loon threshold, stressing the fact that $\mathrm{Hg}$ sensitivity can be species-specific (Heinz et al., 2009), and that toxic effects may appear at lower concentrations in polar environments (Goutte et al., 2014a). Here, the hatching date and success, as well as the chick survival of Antarctic petrels were not related to $\mathrm{Hg}$ exposure. This result highlights that the current levels of exposure to Hg might not be of concern to Antarctic petrels. Yet, further studies should confirm this trend, by focusing on other fitness traits and other phases of the birds' annual cycle (Tartu et al., 2013; Fort et al., 2014). Pre-laying $\mathrm{Hg}$ exposure is governed by feeding intake on early breeding grounds, but also on burdens previously accumulated in wintering habitats. During the long polar winter, Antarctic petrels remain in Antarctic waters, but they increase their foraging range (Descamps et al., 2016b), potentially increasing exposure to food webs with contrasting Hg concentrations. Measuring $\mathrm{Hg}$ concentrations in feathers, or in blood upon arrival at the colony, will be necessary to better evaluate long-term and pre-breeding $\mathrm{Hg}$ exposure in Antarctic petrels. Hg contamination in birds has the potential to modify physiological functions, such as energy metabolism, which is associated with detoxification mechanisms (Lucia et al., 2012). Although such modifications might not have immediate consequences on fitness, they might alter an individual's body condition. Body-condition can be an important determinant of fitness-related traits including breeding success and survival (Labocha and Hayes, 2012). In our study, body condition was not related to blood $\mathrm{Hg}$ concentrations, further highlighting that current $\mathrm{Hg}$ concentrations are not of concern to Antarctic petrels. However, Goutte et al. (2014a,b) reported that blood Hg concentrations were negatively related to long-term breeding success in wandering albatrosses Diomedea exulans and brown skuas Stercorarius antarcticus, without a link to current reproduction. Furthermore, species living in high Antarctic regions were shown to be more sensitive to the negative reproductive effects of Hg (Goutte et al., 2014a,b). This is likely because these species are exposed to increasing environmental stress factors, such as changes in large- and small-scale climatic events, and could thus be affected by $\mathrm{Hg}$ burdens even when no "acute" toxicity is observed. Demographic parameters of the Antarctic petrel population at Svarthamaren are explained by large-scale climatic oscillations and by the occurrence of extreme events such as snow storms (Descamps et al., 2015, 2016a). Yet, even when accounting for these environmental factors, chick production and adult survival have significantly declined in the last three decades (Descamps et al., 2016a). There is therefore an important need to determine whether exposure to $\mathrm{Hg}$ or other environmental contaminants could contribute to this decline through long-term effects.

\section{Conclusions}

This study confirms that feeding ecology plays a key role in $\mathrm{Hg}$ exposure in seabirds, even at the population level. Yet, the large unexplained part of total variation in blood $\mathrm{Hg}$ concentrations warrants more studies on physiological parameters that could influence individual differences. The level of exposure to $\mathrm{Hg}$ in Antarctic petrels is low at present, and with non-detectable effects on current reproduction and body condition. Nonetheless, and despite a recent decrease in $\mathrm{Hg}$ emissions on a global scale (Zhang et al., 2016), the temporal lag between emissions of $\mathrm{Hg}$ and its integration in marine food webs (Driscoll et al., 2013; Fitzgerald et al., 2007) might enhance exposure of Antarctic petrels and Antarctic biota in the future. Importantly, a reorganisation of food web structure and/or a modification in food availability following largescale environmental change might also modify $\mathrm{Hg}$ intake by Antarctic petrels (Braune et al., 2014a), in particular if krill abundance decreases (Kawaguchi et al., 2013). Furthermore, Antarctic biota is exposed to a complex mixture of environmental contaminants that could have synergistic or antagonistic effects on physiology and reproduction. For all these reasons, future monitoring actions of $\mathrm{Hg}$ and other contaminants in this vulnerable Antarctic seabird population are needed.

\section{Acknowledgments}

The authors are grateful to the Plateforme Analyses Elémentaires and the Plateforme Analyses Isotopiques of the LIENSs laboratory for the access to their analytical facilities, and in particular to G. Guillou for running stable isotope analysis. Dr. H. Weimerskirch and the IUF (Institut Universitaire de France) are acknowledged for their support to $A C$ and $P B$, respectively. $A C$ is also grateful to L. Avila and his family for their kind help and hospitality.

\section{Appendix A. Supplementary data}

Supplementary data related to this article can be found at https://doi.org/10.1016/j.envpol.2017.11.004.

\section{References}

Agusa, T., Matsumoto, T. Ikemoto, T., Anan, Y., Kubota, R., Yasunaga, G., Kunito, T. Tanabe, S., Ogi, H., Shibata, Y., 2005. Body distribution of trace elements in black-tailed gulls from Rishiri Island, Japan: age-dependent accumulation and transfer to feathers and eggs. Environ. Toxicol. Chem. 24, 2107-2120.

Ancora, S., Volpi, V., Olmastroni, S., Focardi, S., Leonzio, C., 2002. Assumption and elimination of trace elements in Adélie penguins from Antarctica: a preliminary study. Mar. Environ. Res. 54, 341-344. https://doi.org/10.1016/S0141-1136(02) 00198-8.

Anderson, O.R.J., Phillips, R.A., McDonald, R.A., Shore, R.F., McGill, R.A.R., Bearhop, S. 2009. Influence of trophic position and foraging range on mercury levels within a seabird community. Mar. Ecol. Prog. Ser. 375, 277-288.

Atwell, L., Hobson, K.A., Welch, H.E., 1998. Biomagnification and bioaccumulation of mercury in an arctic marine food web: insights from stable nitrogen isotope analysis. Can. J. Fish. Aquat. Sci. 55, 1114-1121. 
Barbraud, C., Weimerskirch, H., 2001. Emperor penguins and climate change. Nature 411, 183-186. https://doi.org/10.1038/35075554.

Bargagli, R., Monaci, F., Sanchez-Hernandez, J.C., Cateni, D., 1998. Biomagnification of mercury in an Antarctic marine coastal food web. Mar. Ecol. Prog. Ser. 169, 65-76.

Bearhop, S., Ruxton, G.D., Furness, R.W., 2000. Dynamics of mercury in blood and feathers of great skuas. Environ. Toxicol. Chem. 19, 1638-1643.

BirdLife International, 2004. Tracking ocean wanderers: the global distribution of albatrosses and petrels. In: Results from the Global Procellariiform Tracking Workshop. 1-5 September 2003, Gordon's Bay, South Africa. BirdLife International, Cambridge, UK.

Bond, A.L., Diamond, A.W., 2009. Mercury concentrations in seabird tissues from machias seal Island, New Brunswick, Canada. Sci. Total Environ. 407, 4340-4347.

Bond, A.L., Hobson, K.A., Branfireun, B.A., 2015. Rapidly increasing methyl mercury in endangered ivory gull (Pagophila eburnea) feathers over a 130 year record. Proc. R. Soc. Lond. B Biol. Sci. 282, 20150032.

Brasso, R.L., Chiaradia, A., Polito, M.J., Raya Rey, A., Emslie, S.D., 2015 A comprehensive assessment of mercury exposure in penguin populations throughout the Southern Hemisphere: using trophic calculations to identify sources of population-level variation. Mar. Pollut. Bull. 97, 408-418. https:/| doi.org/10.1016/j.marpolbul.2015.05.059.

Brasso, R.L., Polito, M.J., Emslie, S.D., 2014. Multi-tissue analyses reveal limited interannual and seasonal variation in mercury exposure in an Antarctic penguin community. Ecotoxicology 1-11.

Brasso, R.L., Polito, M.J., Lynch, H.J., Naveen, R., Emslie, S.D., 2012. Penguin eggshell membranes reflect homogeneity of mercury in the marine food web surrounding the Antarctic Peninsula. Sci. Total Environ. 439, 165-171.

Braune, B.M., Gaston, A.J., Hobson, K.A., Gilchrist, H.G., Mallory, M.L., 2014a. Changes in food web structure alter trends of mercury uptake at two seabird colonies in the canadian arctic. Environ. Sci. Technol. 48, 13246-13252. https://doi.org/ 10.1021/es5036249.

Braune, B.M., Gaston, A.J., Gilchrist, H.G., Mallory, M.L., Provencher, J.F., 2014b. A geographical comparison of mercury in seabirds in the eastern Canadian Arctic. Environ. Int. 66, 92-96.

Burnham, K.P., Anderson, D.R., 2002. Model Selection and Multi-model Inference: a Practical Information-theoretic Approach, second ed. Springer, New York.

Bustamante, P., Lahaye, V., Durnez, C., Churlaud, C., Caurant, F., 2006. Total and organic $\mathrm{Hg}$ concentrations in cephalopods from the North Eastern Atlantic waters: influence of geographical origin and feeding ecology. Sci. Total Environ. 368, 585-596.

Calle, P., Alvarado, O., Monserrate, L., Cevallos, J.M., Calle, N., Alava, J.J., 2015. Mercury accumulation in sediments and seabird feathers from the Antarctic Peninsula. Mar. Pollut. Bull. 91, 410-417. https://doi.org/10.1016/j.marpolbul.2014.10.009. Marine pollution and assessment of marine status in Latin America.

Carravieri, A., Bustamante, P., Tartu, S., Meillère, A., Labadie, P., Budzinski, H., Peluhet, L., Barbraud, C., Weimerskirch, H., Chastel, O., Cherel, Y., 2014a. Wandering albatrosses document latitudinal variations in the transfer of persistent organic pollutants and mercury to Southern Ocean predators. Environ. Sci. Technol. https://doi.org/10.1021/es504601m.

Carravieri, A., Cherel, Y., Blévin, P., Brault-Favrou, M., Chastel, O., Bustamante, P. 2014b. Mercury exposure in a large subantarctic avian community. Environ. Pollut. 190, 51-57. https://doi.org/10.1016/j.envpol.2014.03.017.

Carravieri, A., Cherel, Y., Brault-Favrou, M., Churlaud, C., Peluhet, L., Labadie, P., Budzinski, H., Chastel, O., Bustamante, P., 2017. From Antarctica to the subtropics: contrasted geographical concentrations of selenium, mercury, and persistent organic pollutants in skua chicks (Catharacta spp.). Environ. Pollut. 228, 464-473. https://doi.org/10.1016/j.envpol.2017.05.053.

Carravieri, A., Cherel, Y., Jaeger, A., Churlaud, C., Bustamante, P., 2016. Penguins as bioindicators of mercury contamination in the southern Indian Ocean: geographical and temporal trends. Environ. Pollut. 213, 195-205. https:/ doi.org/10.1016/j.envpol.2016.02.010.

Cherel, Y., 2008. Isotopic niches of emperor and Adélie penguins in Adélie land Antarctica. Mar. Biol. 154, 813-821.

Cherel, Y., Koubbi, P., Giraldo, C., Penot, F., Tavernier, E., Moteki, M., Ozouf-Costaz, C., Causse, R., Chartier, A., Hosie, G., 2011. Isotopic niches of fishes in coastal, neritic and oceanic waters off Adélie land, Antarctica. Polar Sci. 5, 286-297. https:/ doi.org/10.1016/j.polar.2010.12.004. CEAMARC - The Collaborative East Antarctic Marine Census for the Census of Antarctic Marine Life.

Cherel, Y., Connan, M., Jaeger, A., Richard, P., 2014. Seabird year-round and historical feeding ecology: blood and feather $\delta 13 \mathrm{C}$ and $\delta 15 \mathrm{~N}$ values document foraging plasticity of small sympatric petrels. Mar. Ecol. Prog. Ser. 505, 267-280.

Cipro, C.V., Montone, R.C., Bustamante, P., 2017a. Mercury in the ecosystem of admiralty Bay, king George Island, Antarctica: occurrence and trophic distri bution. Mar. Pollut. Bull. 114, 564-570.

Cipro, C.V.Z., Cherel, Y., Bocher, P., Caurant, F., Miramand, P., Bustamante, P., 2017b. Trace elements in invertebrates and fish from Kerguelen waters, southern Indian Ocean. Polar Biol. 1-17. https://doi.org/10.1007/s00300-017-2180-6.

Crawley, M.J., 2007. The R Book. Wiley.

Descamps, S., Tarroux, A., Lorentsen, S.-Hakon, Love, O.P., Varpe, Ø., Yoccoz, N.G. 2016b. Large-scale oceanographic fluctuations drive Antarctic petrel survival and reproduction. Ecography 39, 496-505.

Descamps, S., Tarroux, A., Cherel, Y., Delord, K., Godø, O.R., Kato, A., Krafft, B.A. Lorentsen, S.-H., Ropert-Coudert, Y., Skaret, G., Varpe, Ø., 2016a. At-Sea distribution and prey selection of antarctic petrels and commercial krill fisheries. PLoS One 11, e0156968. https://doi.org/10.1371/journal.pone.0156968.

Descamps, S., Tarroux, A., Varpe, Ø., Yoccoz, N.G., Tveraa, T., Lorentsen, S.-Hakon, 2015. Demographic effects of extreme weather events: snow storms, breeding success, and population growth rate in a long-lived Antarctic seabird. Ecol. Evol. 5, 314-325.

Dietz, R., Sonne, C., Basu, N., Braune, B., O'Hara, T., Letcher, R.J., Scheuhammer, T., Andersen, M., Andreasen, C., Andriashek, D., Asmund, G., Aubail, A., Baagøe, H., Born, E.W., Chan, H.M., Derocher, A.E., Grandjean, P., Knott, K., Kirkegaard, M., Krey, A., Lunn, N., Messier, F., Obbard, M., Olsen, M.T., Ostertag, S., Peacock, E., Renzoni, A., Rigét, F.F., Skaare, J.U., Stern, G., Stirling, I., Taylor, M., Wiig, Ø., Wilson, S., Aars, J., 2013. What are the toxicological effects of mercury in Arctic biota? Sci. Total Environ. 443, 775-790. https://doi.org/10.1016/ j.scitotenv.2012.11.046.

dos Santos, I.R., Silva-Filho, E.V., Schaefer, C., Maria Sella, S., Silva, C.A., Gomes, V., Passos, M.J. de A.C.R., Van Ngan, P., 2006. Baseline mercury and zinc concentrations in terrestrial and coastal organisms of Admiralty Bay, Antarctica. Environ. Pollut. 140, 304-311. https://doi.org/10.1016/j.envpol.2005.07.007.

Driscoll, C.T., Mason, R.P., Chan, H.M., Jacob, D.J., Pirrone, N., 2013. Mercury as a global pollutant: sources, pathways, and effects. Environ. Sci. Technol. 47, 4967-4983.

Ebinghaus, R., Kock, H.H., Temme, C., Einax, J.W., Löwe, A.G., Richter, A., Burrows, J.P., Schroeder, W.H., 2002. Antarctic springtime depletion of atmospheric mercury. Environ. Sci. Technol. 36, 1238-1244.

Evers, D.C., Savoy, L.J., DeSorbo, C.R., Yates, D.E., Hanson, W., Taylor, K.M., Siegel, L.S., Cooley Jr., J.H., Bank, M.S., Major, A., 2008. Adverse effects from environmental mercury loads on breeding common loons. Ecotoxicology 17, 69-81.

Fitzgerald, W.F., Lamborg, C.H., Hammerschmidt, C.R., 2007. Marine biogeochemical cycling of mercury. Chem. Rev. 107, 641-662.

Fort, J., Grémillet, D., Traisnel, G., Amélineau, F., Bustamante, P., 2016. Does temporal variation of mercury levels in Arctic seabirds reflect changes in global environmental contamination, or a modification of Arctic marine food web functioning? Environ. Pollut. 211, 382-388.

Fort, J., Lacoue-Labarthe, T., Nguyen, H.L., Boué, A., Spitz, J., Bustamante, P. 2015 Mercury in wintering seabirds, an aggravating factor to winter wrecks? Sci. Total Environ. 527, 448-454.

Fort, J., Robertson, G.J., Grémillet, D., Traisnel, G., Bustamante, P., 2014. Spatial ecotoxicology: migratory Arctic seabirds are exposed to mercury contamination while overwintering in the northwest Atlantic. Environ. Sci. Technol. 48, $11560-11567$.

Fromant, A., Carravieri, A., Bustamante, P., Labadie, P., Budzinski, H., Peluhet, L. Churlaud, C., Chastel, O., Cherel, Y., 2016. Wide range of metallic and organic contaminants in various tissues of the Antarctic prion, a planktonophagous seabird from the Southern Ocean. Sci. Total Environ. 544, 754-764. https:// doi.org/10.1016/j.scitotenv.2015.11.114.

Goutte, A., Barbraud, C., Herzke, D., Bustamante, P., Angelier, F., Tartu, S., ClémentChastel, C., Moe, B., Bech, C., Gabrielsen, G.W., et al., 2015. Survival rate and breeding outputs in a high Arctic seabird exposed to legacy persistent organic pollutants and mercury. Environ. Pollut. 200,1-9.

Goutte, A., Barbraud, C., Meillère, A., Carravieri, A., Bustamante, P., Labadie, P., Budzinski, H., Delord, K., Cherel, Y., Weimerskirch, H., Chastel, O., 2014a. Demographic consequences of heavy metals and persistent organic pollutants in a vulnerable long-lived bird, the wandering albatross. Proc. R. Soc. B Biol. Sci. 281, 20133313. https://doi.org/10.1098/rspb.2013.3313.

Goutte, A., Bustamante, P., Barbraud, C., Delord, K., Weimerskirch, H., Chastel, O. 2014b. Demographic responses to mercury exposure in two closely related Antarctic top predators. Ecology 95, 1075-1086. https://doi.org/10.1890/131229.1.

Heinz, G.H., Hoffman, D.J., Klimstra, J.D., Stebbins, K.R., Kondrad, S.L., Erwin, C.A., 2009. Species differences in the sensitivity of avian embryos to methylmercury. Arch. Environ. Contam. Toxicol. 56, 129-138.

Hobson, K.A., Clark, R.G., 1993. Turnover of 13 C in cellular and plasma fractions of blood: implications for nondestructive sampling in avian dietary studies. Auk 638-641.

Jardine, T.D., Cunjak, R.A., 2005. Analytical error in stable isotope ecology. Oecologia 144, 528-533. https://doi.org/10.1007/s00442-005-0013-8.

Jerez, S., Motas, M., Palacios, M.J., Valera, F., Cuervo, J.J., Barbosa, A., 2011. Concentration of trace elements in feathers of three Antarctic penguins: geographical and interspecific differences. Environ. Pollut. 159, 2412-2419. https://doi.org/ 10.1016/j.envpol.2011.06.036. Nitrogen Deposition, Critical Loads and Biodiversity.

Kallenborn, R., Breivik, K., Eckhardt, S., Lunder, C.R., Manø, S., Schlabach, M. Stohl, A., 2013. Long-term monitoring of persistent organic pollutants (POPs) at the Norwegian Troll station in Dronning Maud Land, Antarctica. Atmos. Chem. Phys. 13, 6983-6992.

Kawaguchi, S., Ishida, A., King, R., Raymond, B., Waller, N., Constable, A., Nicol, S. Wakita, M., Ishimatsu, A., 2013. Risk maps for Antarctic krill under projected Southern Ocean acidification. Nat. Clim. Change 3, 843-847. https://doi.org/ 10.1038/nclimate1937.

Labocha, M.K., Hayes, J.P., 2012. Morphometric indices of body condition in birds: a review. J. Ornithol. 153, 1-22. https://doi.org/10.1007/s10336-011-0706-1.

Lorentsen, S.-H., Klages, N., Røv, N., 1998. Diet and prey consumption of antarctic petrels Thalassoica Antarctica at Svarthamaren, dronning Maud land, and at sea outside the colony. Polar Biol. 19, 414-420. https://doi.org/10.1007/ s003000050267. 
Lorentsen, S.-H., Røv, N., 1995. Incubation and brooding performance of the antarctic petrel Thalassoica Antarctica at Svarthamaren, dronning Maud land. Ibis 137, 345-351. https://doi.org/10.1111/j.1474-919X.1995.tb08031.x.

Lucia, M., Bocher, P., Cosson, R.P., Churlaud, C., Robin, F., Bustamante, P., 2012. Insight on trace element detoxification in the Black-tailed Godwit (Limosa limosa) through genetic, enzymatic and metallothionein analyses. Sci. Total Environ. 423, 73-83. https://doi.org/10.1016/j.scitotenv.2012.02.005.

Mastromonaco, M. Nerentorp, Gårdfeldt, K., Jourdain, B., Abrahamsson, K., Granfors, A., Ahnoff, M., Dommergue, A., Méjean, G., Jacobi, H.-W., 2016. Antarctic winter mercury and ozone depletion events over sea ice. Atmos. Environ. 129, 125-132. https://doi.org/10.1016/j.atmosenv.2016.01.023.

Mehlum, F., Gjessing, Y., Haftorn, S., Bech, C., 1988. Census of breeding Antarctic petrels Thalassoica Antarctica and physical features of the breeding colony at Svarthamaren, Dronning Maud Land, with notes on breeding snow petrels Pagodroma nivea and south polar skuas Catharacta maccormicki. Polar Res. 6, 1-9. https://doi.org/10.3402/polar.v6i1.6841.

Meillère, A., Brischoux, F., Parenteau, C., Angelier, F., 2015. Influence of urbanization on body size, condition, and physiology in an urban exploiter: a multicomponent approach. PLoS One 10, e0135685. https://doi.org/10.1371/ journal.pone.0135685.

Monteiro, L.R., Furness, R.W., 2001. Kinetics, dose-response, and excretion of methylmercury in free-living adult Cory's shearwaters. Environ. Sci. Technol. 35, 739-746. https://doi.org/10.1021/es000114a.

Morel, F.M.M., Kraepiel, A.M.L., Amyot, M., 1998. The chemical cycle and bioaccumulation of mercury. Annu. Rev. Ecol. Syst. 29, 543-566.

Newsome, S.D., Martinez del Rio, C., Bearhop, S., Phillips, D.L., 2007. A niche for isotopic ecology. Front. Ecol. Environ. 5, 429-436.

Nygård, T., Lie, E., Røv, N., Steinnes, E., 2001. Metal dynamics in an antarctic food chain. Mar. Pollut. Bull. 42, 598-602. https://doi.org/10.1016/S0025-326X(00) 00206-X.

Peig, J., Green, A.J., 2010. The paradigm of body condition: a critical reappraisal of current methods based on mass and length. Funct. Ecol. 24, 1323-1332.

Peig, J., Green, A.J., 2009. New perspectives for estimating body condition from mass/length data: the scaled mass index as an alternative method. Oikos 118, 1883-1891.

Pinheiro, J., Bates, D., DebRoy, S., Sarkar, D., EISPACK, Heisterkamp, S., Van Willigen, B., 2017. Package "nlme". Linear and Nonlinear Mixed Effects Models.

Polito, M.J., Brasso, R.L., Trivelpiece, W.Z., Karnovsky, N., Patterson, W.P., Emslie, S.D., 2016. Differing foraging strategies influence mercury $(\mathrm{Hg})$ exposure in an Antarctic penguin community. Environ. Pollut. 218, 196-206.

Provencher, J.F., Gilchrist, H.G., Mallory, M.L., Mitchell, G.W., Forbes, M.R., 2016 Direct and indirect causes of sex differences in mercury concentrations and parasitic infections in a marine bird. Sci. Total Environ. 551-552, 506-512.

R Core Team, 2016. R: a Language and Environment for Statistical Computing.

Reid, K., Croxall, J.P., Edwards, T.M., 1997. Interannual variation in the diet of the antarctic prion Pachyptila desolata at South Georgia. Emu 97, 126-132. https:// doi.org/10.1071/mu97016.

Robinson, S.A., Lajeunesse, M.J., Forbes, M.R., 2012. Sex differences in mercury contamination of birds: testing multiple hypotheses with meta-analysis. Environ. Sci. Technol. 46, 7094-7101. https://doi.org/10.1021/es204032m.

Scheuhammer, A., Braune, B., Chan, H.M., Frouin, H., Krey, A., Letcher, R., Loseto, L. Noël, M., Ostertag, S., Ross, P., Wayland, M., 2015. Recent progress on our understanding of the biological effects of mercury in fish and wildlife in the Canadian. Arct. Sci. Total Environ. 509, 91-103. https://doi.org/10.1016/j.scitotenv.2014.05.142. Special Issue: Mercury in Canada's North.

Scheuhammer, A.M., Meyer, M.W., Sandheinrich, M.B., Murray, M.W., 2007. Effects of environmental methylmercury on the health of wild birds, mammals, and fish. AMBIO J. Hum. Environ. 36, 12-19. https://doi.org/10.1579/00447447(2007)36[12:EOEMOT]2.0.CO;2.

Tan, S.W., Meiller, J.C., Mahaffey, K.R., 2009. The endocrine effects of mercury in humans and wildlife. Crit. Rev. Toxicol. 39, 228-269. https://doi.org/10.1080/ 10408440802233259

Tarroux, A., Weimerskirch, H., Wang, S.-H., Bromwich, D.H., Cherel, Y., Kato, A. Ropert-Coudert, Y., Varpe, Ø., Yoccoz, N.G., Descamps, S., 2016. Flexible flight response to challenging wind conditions in a commuting Antarctic seabird: do you catch the drift? Anim. Behav. 113, 99-112.

Tartu, S., Angelier, F., Wingfield, J.C., Bustamante, P., Labadie, P., Budzinski, H. Weimerskirch, H., Bustnes, J.O., Chastel, O., 2015. Corticosterone, prolactin and egg neglect behavior in relation to mercury and legacy POPs in a long-lived Antarctic bird. Sci. Total Environ. 505, 180-188. https://doi.org/10.1016/ j.scitotenv.2014.10.008.

Tartu, S., Bustamante, P., Angelier, F., Lendvai, Á.Z., Moe, B., Blévin, P., Bech, C. Gabrielsen, G.W., Bustnes, J.O., Chastel, O., 2016. Mercury exposure, stress and prolactin secretion in an Arctic seabird: an experimental study. Funct. Ecol. 30 596-604. https://doi.org/10.1111/1365-2435.12534.

Tartu, S., Bustamante, P., Goutte, A., Cherel, Y., Weimerskirch, H., Bustnes, J.O. Chastel, O., 2014. Age-related mercury contamination and relationship with luteinizing hormone in a long-lived antarctic bird. PLoS One 9, e103642. https:/ doi.org/10.1371/journal.pone.0103642.

Tartu, S., Goutte, A., Bustamante, P., Angelier, F., Moe, B., Clément-Chastel, C. Bech, C., Gabrielsen, G.W., Bustnes, J.O., Chastel, O., 2013. To breed or not to breed: endocrine response to mercury contamination by an Arctic seabird. Biol. Lett. 9, 20130317. https://doi.org/10.1098/rsbl.2013.0317.

Tavares, S., Xavier, J.C., Phillips, R.A., Pereira, M.E., Pardal, M.A., 2013. Influence of age, sex and breeding status on mercury accumulation patterns in the wandering albatross Diomedea exulans. Environ. Pollut. 181, 315-320.

van Franeker, J.A., Gavrilo, M., Mehlum, F., Veit, R.R., Woehler, E.J., 1999. Distribution and abundance of the antarctic petrel. Waterbirds Int. J. Waterbird Biol. 22 14-28. https://doi.org/10.2307/1521989.

Wayland, M., Gilchrist, H.G., Marchant, T., Keating, J., Smits, J.E., 2002. Immune function, stress response, and body condition in arctic-breeding common eiders in relation to cadmium, mercury, and selenium concentrations. Environ. Res. 90 47-60. https://doi.org/10.1006/enrs.2002.4384.

Wolfe, M.F., Schwarzbach, S., Sulaiman, R.A., 1998. Effects of mercury on wildlife: a comprehensive review. Environ. Toxicol. Chem. 17, 146-160.

Xavier, J.C., Trathan, P.N., Ceia, F.R., Tarling, G.A., Adlard, S., Fox, D., Edwards, E.W.J., Vieira, R.P., Medeiros, R., Broyer, C.D., Cherel, Y., 2017. Sexual and individual foraging segregation in Gentoo penguins Pygoscelis papua from the Southern Ocean during an abnormal winter. PLoS One 12, e0174850. https://doi.org/ 10.1371 journal.pone.0174850.

Zhang, Y., Jacob, D.J., Horowitz, H.M., Chen, L., Amos, H.M., Krabbenhoft, D.P., Slemr, F., Louis, V.L.S., Sunderland, E.M., 2016. Observed decrease in atmospheric mercury explained by global decline in anthropogenic emissions. Proc. Natl. Acad. Sci. 113, 526-531. https://doi.org/10.1073/pnas.1516312113. 